\title{
THE INFLUENCE OF SPATIAL HIERARCHY AND FUNCTION ON THE ARCHITECTURE OF THE MAIN BUILDING OF CIREBON'S KEJAKSAN RAILWAY STATION
}

\author{
${ }^{1}$ Nasya Nabilla Aninditya. ${ }^{2}$ Dr. Ir. Bachtiar Fauzy, M.T. \\ ${ }^{1}$ Student in the Bachelor's (S-1) Study Program in Architecture \\ at Parahyangan Catholic University \\ ${ }^{2}$ Senior lecturer in the Bachelor's (S-1) Study Program in Architecture \\ at Parahyangan Catholic University
}

\begin{abstract}
The Cirebon region was once one of the centers for sugar plantations on Java. In the middle of the 19th century the town of Cirebon developed an urban area revolving around the food industry whose main products were sugar and ice. To facilitate the distribution of sugar in large quantities, the State Railway Service built the Cirebon Railway Station in the Kejaksan town district. This was designed and built by a Dutch architect named P.A.J. Mooijen in 1911, in the typical "Indies" style that was in the middle phase of its development. This research study aims to explore the influence of function and hierarchy on its architectural form, namely the main station building on Jalan Siliwangi in the Kejaksan district. The research steps consist of deconstructing and classifying the building, employing Thijs Eversen's theory concerning Archetypes in Architecture, and an examination of function, form, space and ordering principles as described by Francis D.K. Ching. The result of this interpretation is subsequently linked to various indicators that point toward the Indies style of architecture, as proposed by Hardinoto. The final step consists of showing the connection between spatial function and hierarchy found in the building form. The conclusion indicates that spatial function and hierarchy have indeed had a direct impact on the architectural form examined. This is discernible in the building mass that shows a formal hierarchy in the middle, which is in keeping with the hierarchy of building space. The typical Dutch East Indies building concept featuring the use of symmetrical space, a monumental shape due to the hierarchy in the middle section, and the use of supporting walls can all be found in the main building of this railway station.
\end{abstract}

Keywords: Function, Form, Space, Spatial Hierarchy, Dutch East Indies Style of Architecture

\section{PENGARUH FUNGSI DAN HIERARKI RUANG TERHADAP BENTUK ARSITEKTUR BANGUNAN UTAMA STASIUN KEJAKSAN CIREBON}

\author{
${ }^{1}$ Nasya Nabilla Aninditya. ${ }^{2}$ Dr. Ir. Bachtiar Fauzy, M.T. \\ ${ }^{1}$ Mahasiswi S1 Program Studi Arsitektur Universitas Katolik Parahyangan. \\ 2 Dosen Pembimbing S1 Program Studi Arsitektur Universitas Katolik Parahyangan.
}

\begin{abstract}
Abstrak-Wilayah Cirebon merupakan salah satu sentra perkebunan gula di Jawa. Pada pertengahan abad ke-19, Kota Cirebon berkembang menjadi kota industri pangan, dengan produk utama gula dan es. Untuk mempermudah distribusi

${ }^{1}$ Corresponding author: nasyanabilla@hotmail.com
\end{abstract}


gula dalam jumlah besar, perusahaan kereta api negara Staatspoorwegen (SS) membangun Stasiun Cirebon di daerah Kejaksan. Stasiun Kejaksan Cirebon didesain dan dibangun oleh arsitek Belanda bernama Pieter Adriaan Jacobus Moojen pada tahun 1911, dengan gaya arsitektur indis yang tengah berkembang pada masa itu.Penelitian ini bertujuan untuk mengetahui pengaruh fungsi dan hirarki terhadap bentuk arsitektur bangunan objek, yaitu bangunan utama Stasiun Kejaksan Cirebon, yang terletak pada Jl Siliwangi, Wilayah Kejaksan, Kota Cirebon, Jawa Barat. Langkah penelitian adalah dengan membedah bangunan dengan teori archetypes in architecture oleh Thiis-Evensen kemudian dikaji fungsi, bentuk, ruang, dan prinsip penataannya sesuai dengan teori fungsi-bentuk-makna oleh Purnama Salura, serta bentuk, ruang, organisasi, dan ordering principles oleh Francis D. K. Ching. Kemudian hasil penjabaran akan dikaitkan dengan poin-poin indikator arsitektur indis yang dikemukakan oleh Handinoto. Langkah terakhir adalah mengemukakan kaitan fungsi dan hirarki ruang terhadap bentuk bangunan. Kesimpulan yang diperoleh adalah bahwa fungsi dan hirarki ruang memberikan pengaruh langsung terhadap bentuk arsitektur bangunan utama Stasiun Kejaksan Cirebon. Hal ini terlihat jelas dari massa bangunan yang memiliki hirarki bentuk di tengah, sesuai dengan hirarki ruang bangunan. Konsep bangunan indis seperti ruang yang simetris, bentuk monumental karena hirarki di tengah, dan penggunaan dinding pemikul, terdapat pada bangunan utama Stasiun Kejaksan Cirebon.

Kata kunci: Fungsi, Bentuk, Ruang, Hirarki Ruang, Arsitektur Indis

\section{PENDAHULUAN}

Perkembangan arsitektur indis di Kota Cirebon dimulai pada pertengahan abad ke-19 sampai awal abad ke-20, ketika Belanda membangun beberapa bangunan pemerintahan dan bangunan umum, seperti Balai Kota, gedung kantor pos dan bank, gereja, serta stasiun. Pembangunan stasiun di Cirebon oleh perusahaan kereta api negara, Staatspoorwegen (SS), didasarkan pada kebutuhan jalur distribusi pangan lintas Jakarta-Semarang-Surabaya. Stasiun ini menghubungkan jalur Batavia-Cikampek-Cirebon-Purwokerto-Kroya yang merupakan salah satu jalur utama distribusi tebu dan gula di Pulau Jawa.

Stasiun Kejaksan Cirebon dibangun pada tahun 1911 oleh arsitek Belanda Pieter Adriaan Jacobus Moojen dan diresmikan pada tahun 1912. Bangunan utama Stasiun Kejaksan Cirebon merupakan bangunan bergaya arsitektur indis yang masih mempertahankan fungsi dan fisik bangunan seperti pada awalnya berdiri. Karakter bangunan indis sangat terlihat dari bentuknya yang megah, monumental dan memiliki hirarki yang kuat. Fungsi bangunan sebagai stasiun atau tempat aktifitas transit menghasilkan pola ruang dengan hirarki yang berbeda-beda. Adanya perbedaan hirarki ruang mempengaruhi bentuk fisik atau tampilan bangunan dan ornamen yang menyertainya.

Tujuan dari penelitian ini adalah untuk mengetahui dan memahami definisi arsitektur indis serta mengurai bagaimana bentuk pengaruh fungsi dan hirarki ruang terhadap bentuk arsitektur bangunan utama Stasiun Kejaksan Cirebon. Manfaat yang dihasilkan dari penelitian adalah mengungkapkan pengaruh fungsi terhadap bentuk bangunan, memberikan kontribusi dalam ilmu arsitektur, terutama arsitektur indis di Indonesia.

\section{TEORI ORNAMEN BALI DAN ORNAMEN BELANDA}

\subsection{AKULTURASI}

Akulturasi budaya terjadi saat bangsa Belanda datang ke Indonesia. Kebudayaan Belanda

yang menyebar luas di Indonesia perlahan membaur dengan budaya lokal karena adanya 
pernikahan antara bangsa Belanda dengan bangsa Indonesia. Hal-hal seperti bahasa, ilmu pengetahuan, adat-istiadat, dan norma atau hukum dari Indonesia maupun Belanda melebur sehingga menciptakan sebuah cara baru dalam berlaku dan berpikir dalam masyarakat.

Percampuran budaya Belanda dengan Indonesia juga berpengaruh pada arsitektur masa itu. Awalnya, bangunan-bangunan yang dirancang Belanda di Indonesia tidak menyesuaikan dengan lingkungan, namun seiring perkembangan kebudayaan indis, bangsa Belanda mulai memperhatikan bentuk bangunan rumah tradisional Indonesia dan menjadikannya tolak ukur untuk merancang bangunan di iklim tropis. Sehingga terjadilah perpaduan gaya bangunan Belanda dengan bentuk bangunan pada iklim tropis yang disebut arsitektur indis. Beberapa karakter bangunan indis seperti yang diungkapkan Handinoto (1996) adalah sebagai berikut.

Tabel 1. Karakter Bangunan Indis

\begin{tabular}{|c|c|}
\hline Tapak luas dengan penatan renggang pada RS & Bentuk cenderung kubus, terlihat masif, berat, megah, \\
Mata Dr. Yap di Yogyakarta. Terlihat bentuk massa & dan monumental. Tampak depan simetris. (sumber: \\
\hline yang tipis. & google.co.id, 2016) \\
\hline (sumber: Google Earth, 2016) & Penggunaan atap kombinasi pelana dan perisai pada \\
Gedung Sate. Dinding struktural dengan vault. \\
(sumber: google.co.id, 2016)
\end{tabular}


Denah simetris, dengan bangunan utama di tengah, dan bangunan lebih kecil di sisi kiri dan kanan. (sumber: Jurnal Arsitektur Transisi di Nusantara Dari Akhir Abad ke 19 Hingga Awal Abad ke-20, Handinoto \& Hartono)
Ornamen bangunan bercorak kolonial pada dinding Gedung de Vries di Bandung. (sumber: google.co.id, 2016)

\subsection{FUNGSI, BENTUK, RUANG, ORGANISASI DALAM ARSITEKTUR}

Fungsi, bentuk, makna merupakan tiga substansi dasar dalam arsitektur (Purnama Salura, 2010). Fungsi berkaitan dengan konteks, bentuk dengan struktur, sedangkan makna berpasangan dengan tampilan dan pesan. Relasi antara fungsi dan bentuk menciptakan makna. Makna yang diterima oleh pengguna dan pengamat bangunan dapat merujuk kepada fungsi aslinya, ataupun berubah menjadi fungsi baru, maka itu proses pemaknaan sebisa mungkin hanya memperbaiki dan menyempurnakan fungsi awal.

Menurut Francis D. K. Ching dalam buku Architecture: Form, Space and Order (1979), bentuk dasar memiliki beberapa sifat bentuk, yaitu ukuran, warna, dan tekstur. Bentuk dasar adalah persegi, segitiga, dan lingkaran. Bentuk ini menjadi patokan untuk mengidentifikasi serta mengkategorikan bentuk. Ukuran adalah dimensi fisik, panjang, lebar, dan kedalaman sebuah bentuk yang menentukan skala dan proporsi bentuk.

Bentuk juga memiliki bentuk solid primer, yaitu bola, tabung, kerucut, limas, dan kubus. Bentuk ini merupakan wujud tiga dimensional dari peleburan bentuk dasar yang telah disebutkan di atas. Bentuk-bentuk lain yang berkembang dari bentuk solid primer, yang merupakan variasi bentuk, dapat dimunculkan melalui manipulasi satu atau beberapa dimensi atau dengan penambahan maupun pengurangan elemen-elemen. Manipulasi ini disebut transformasi bentuk. Transformasi bentuk berupa adisi, subtraksi, dan transformasi dimensional.

Bentuk-bentuk aditif dan subtraktif dapat menghasilkan beragam bentuk baru dengan organisasi atau penataan tertentu. Bentuk subtraktif dapat menghasilkan profil bentuk baru dengan gabungan dua volume bentuk berbeda, sedangkan bentuk-bentuk aditif dapat menghasilkan komponen dan konfigurasi bentuk seperti, bentuk terpusat, bentuk linear, bentuk radial, bentuk terklaster, dan bentuk grid. Masing-masing bentuk menciptakan ruang yang berbeda-beda. Ruangruang ini dapat diciptakan dari elemen horizontal seperti bidang dasar, bidang dasar yang diangkat dan diturunkan, bidang di atas, dan elemen vertikal berupa elemen linear vertikal, 1 bidang vertikal, sampai 4 bidang penutup yang mengurung ruang.

Organisasi bentuk dan ruang menjelaskan bagaimana ruang dapat terhubung dengan ruang lain dan diatur menjadi pola-pola bentuk yang teratur. Dua buah ruang dapat terhubung satu sama lain dengan beberapa cara mendasar, yaitu ruang dalam ruang, ruang-ruang yang saling mengunci, ruang-ruang yang berdekatan, dan ruang-ruang yang dihubungkan oleh sebuah ruang bersama. 
Tabel 2. Organisasi Bentuk dan Ruang

(sumber: D.K. Ching, 1979)

\begin{tabular}{|c|c|c|c|}
\hline & $\begin{array}{c}\text { Ruang-ruang yang } \\
\text { saling mengunci. }\end{array}$ \\
\hline Ruang dalam ruang. & $\begin{array}{c}\text { Ruang-ruang yang } \\
\text { berdekatan. }\end{array}$ & $\begin{array}{c}\text { Ruang-ruang yang } \\
\text { dihubungkan. }\end{array}$ \\
\hline
\end{tabular}

Prinsip penataan atau ordering principles (D. K. Ching, 1979) merupakan bagian penting dari pembentuk arsitektur. Prinsip tatanan ini digunakan untuk menciptakan tatanan di dalam suatu komposisi arsitektural. Ada enam prinsip penataan, yaitu sumbu, simetri, hirarki, datum, ritma, dan transformasi.

Tabel 3. Ordering Principles

(sumber: D.K. Ching, 1979)

$\begin{aligned} & \text { Sumbu } \\
& \text { Sumbu merupakan suatu garis yang terbentuk oleh dua } \\
& \text { buah titik di dalam ruang, dimana bentuk-bentuk dan } \\
& \text { ruang-ruang dapat disusun secara teratur ataupun tidak } \\
& \text { teratur. }\end{aligned}$
$\begin{aligned} & \text { Simetri } \\
& \begin{array}{l}\text { Simetri dalam ruang muncul dikarenakan adanya pola- } \\
\text { pola bentuk dan ruang pada sisi yang berlawanan secara } \\
\text { seimbang. }\end{array}\end{aligned}$
\begin{tabular}{l} 
(sumber: google.co.id, 2016) \\
\hline
\end{tabular}

\section{Hirarki}

Hirarki pada bentuk dan ruang berguna untuk memberikan makna bahwa sebuah bentuk dan ruang tersebut signifikan atau dominan. Perbedaan ukuran, wujud, dan penempatan dapat menentukan hirarki.
Hirarki pada Gedung Sate, Bandung

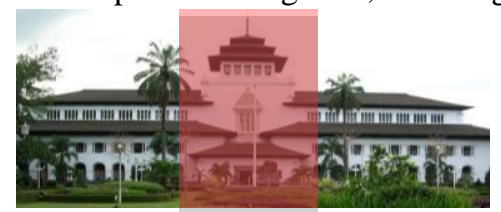

(sumber: google.co.id, 2016) 


$\begin{aligned} & \text { Datum } \\ & \text { Datum diartikan sebagai suatu garis, bidang, atau volume } \\ & \text { acuan yang dapat menyatukan unsur-unsur lain di dalam } \\ & \text { suatu komposisi. Datum mengorganisir suatu pola acak } \\ & \text { unsur-unsur melalui keteraturan, kontinuitas, dan } \\ & \text { keberadaannya yang konstan. }\end{aligned}$
$\begin{aligned} & \text { Ritma } \\ & \text { Pengulangan pola bentuk dan susunan yang teratur pada } \\ & \text { suatu bangunan menciptakan ritma atau irama pada } \\ & \text { bangunan. }\end{aligned}$

\subsection{ARCHETYPES IN ARCHITECTURE}

Thomas Thiis-Evensen (1987) mengatakan bahwa ada tiga elemen pembentuk dasar arsitektur, yaitu kepala (roof), badan (wall), dan kaki bangunan (floor). Ketiga elemen ini membentuk ruang dalam suatu bangunan dan menghubungkannya dengan lingkungan luar bangunan dengan cara yang berbeda. Roof melalui ruang di bawah naungannya dan di atasnya, wall melalui ruang yang diselimutinya dan ruang di sekeliling luarnya, sedangkan floor melalui ruang di atasnya dan di bawahnya.

Analisis akan dilakukan dengan cara membedah bangunan dengan teori archetypes in architecture oleh Thiis-Evensen kemudian dikaji fungsi, bentuk, ruang, dan prinsip penataannya sesuai dengan teori fungsi-bentuk-makna oleh Purnama Salura, serta bentuk, ruang, organisasi, dan ordering principles oleh Francis D. K. Ching. Kemudian hasil penjabaran akan dikaitkan dengan poin-poin indikator arsitektur indis yang dikemukakan oleh Handinoto. Elemen-elemen pembentuk arsitektur indis akan dijabarkan mulai dari tapak, bentuk, kepala bangunan, ruang, dinding, lantai, serta ornamen. Setelah itu, pembahasan akan mengerucut pada bagaimana fungsi dan hirarki ruang mempengaruhi bentuk fisik yang mencakup elemen pelingkup bangunan serta ornamen bangunan. 


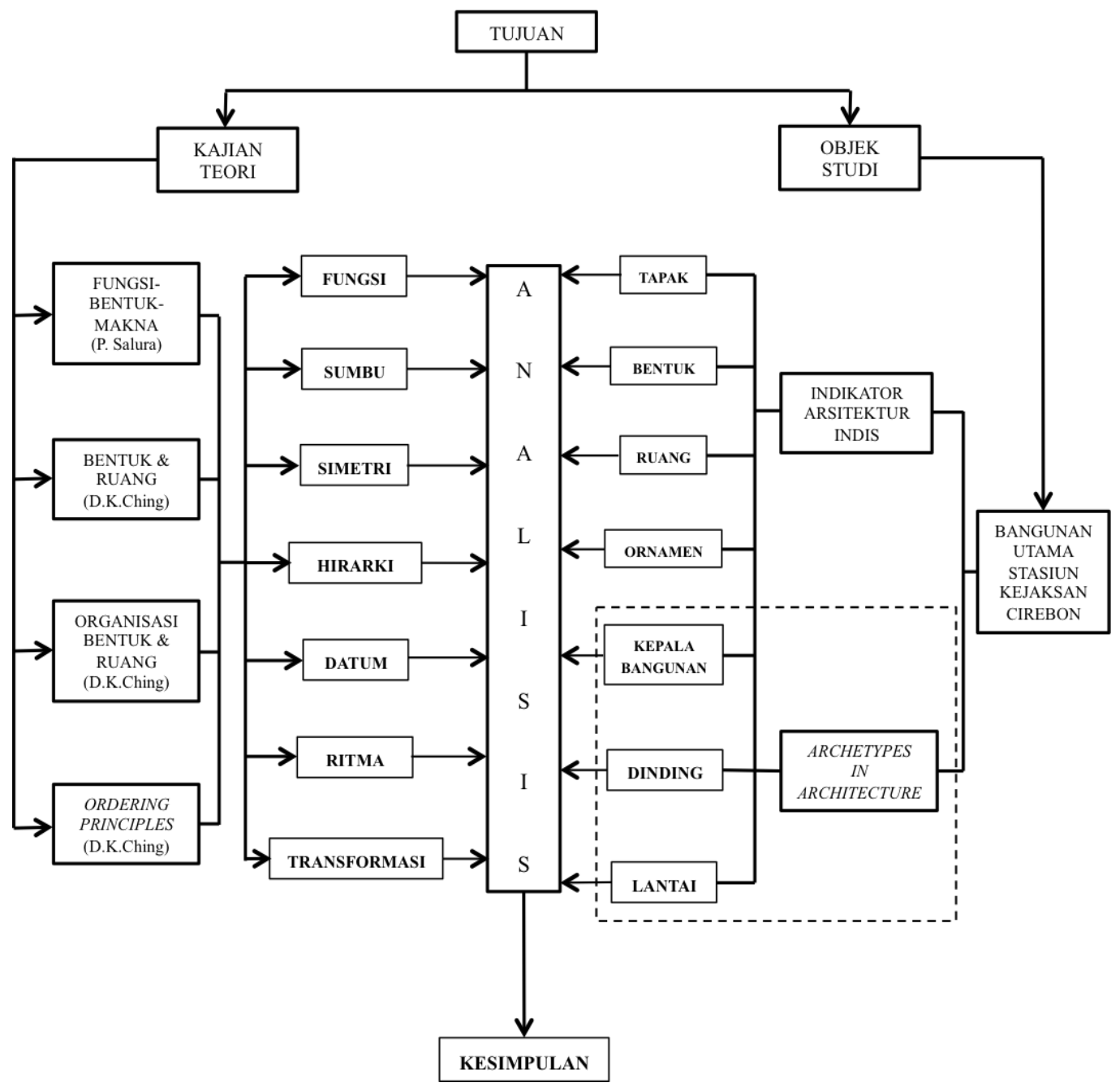

Figur 1. Kerangka Konseptual

\section{PEMBAHASAN}

\subsection{ARSITEKTUR BANGUNAN UTAMA STASIUN KEJAKSAN CIREBON}

Bangunan yang menjadi objek penelitian ini adalah bangunan utama Stasiun Kejaksan Cirebon yang berlokasi di Jalan Siliwangi, Wilayah Kejaksan, Kota Cirebon, Jawa Barat. Bangunan ini berfungsi sebagai stasiun kereta jalur Utara Pulau Jawa dari sejak dibangun tahun 1911 sampai sekarang.

Tabel 4. Data Objek

\begin{tabular}{|l|l|}
\hline Nama Bangunan & Stasiun Kejaksan Cirebon (bangunan utama) \\
\hline Arsitek & Pieter Adriaan Jacobus Moojen \\
\hline Tahun Dibangun & 1911 \\
\hline Alamat & J1. Raya Siliwangi, Kejaksan, Kelurahan Kebonbaru, Kota Cirebon, Jawa Barat \\
\hline
\end{tabular}




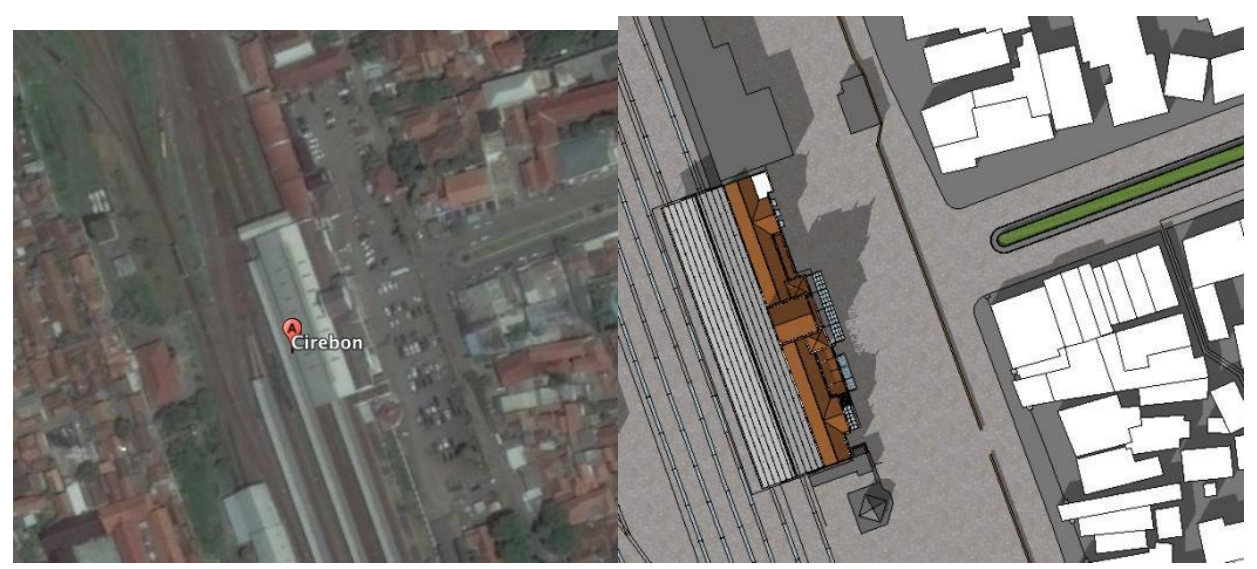

Figur 2. Kawasan Objek Studi (sumber: Google Earth, 2016)

\subsubsection{SEJARAH}

Wilayah Cirebon merupakan salah satu sentra perkebunan gula di Jawa. Pada pertengahan abad ke-19, Kota Cirebon berkembang menjadi kota industri pangan, dengan produk utama gula dan es. Untuk mempermudah distribusi gula dalam jumlah besar, perusahaan kereta api negara Staatspoorwegen (SS) mengembangkan jalur kereta ke Utara pulau Jawa dengan membangun Stasiun Cirebon di daerah Kejaksan.

Stasiun Kejaksan Cirebon didesain oleh arsitek Belanda bernama Pieter Adriaan Jacobus Moojen dan dibangun pada tahun 1911. Diresmikan pada tahun 1912 bersamaan dengan dibukanya lintas Cikampek-Cirebon sejauh 137 km. Stasiun ini menghubungkan jalur Batavia-CikampekCirebon-Purwokerto-Kroya yang merupakan salah satu jalur utama distribusi tebu dan gula di Pulau Jawa.

Tidak begitu banyak perubahan yang terjadi pada bangunan utama Stasiun Kejaksan Cirebon. Beberapa perubahan untuk menyesuaikan dengan kondisi sekarang di antaranya, dua menaranya yang sekarang bertuliskan "CIREBON" dulu bertuliskan "kaartjes" (karcis) di sebelah kiri dan "baggage" (bagasi) di sebelah kanan. Pada tahun 1984, gedung stasiun ini dicat putih. Kemudian pada tahun 2011, Stasiun Kejaksan Cirebon direnovasi dengan meninggikan peron stasiun serta menambah jalur dan fasilitas umum.

\subsubsection{KONDISI LINGKUNGAN}

Stasiun Kejaksan Cirebon terletak di sebelah Utara Kota Cirebon, sejajar dengan Balai Kota dan Alun-Alun Kejaksan yang terletak pada Jalan Raya Siliwangi. Stasiun Kejaksan Cirebon dikelilingi oleh fungsi-fungsi seperti masjid, kantor, tempat makan, hotel, tempat oleh-oleh, toko grosir, dan permukiman. Fungsi-fungsi komersil yang mengelilingi wilayah stasiun muncul karena kebutuhan pengguna stasiun yang singgah sementara waktu dan menunggu.

\subsubsection{WUJUD ARSITEKTUR}

Bangunan utama Stasiun Kejaksan Cirebon memiliki satu massa dengan adisi pada bagian belakang, yaitu bagian peron. Bagian tengah merupakan bagian hall penerima, sebelah kiri adalah 
loket penjualan tiket kereta dan retail, sedangkan bagian kanan adalah ruang VIP untuk tamu penting dan retail. Atap peron adalah struktur baja bentang lebar dengan penutup seng.

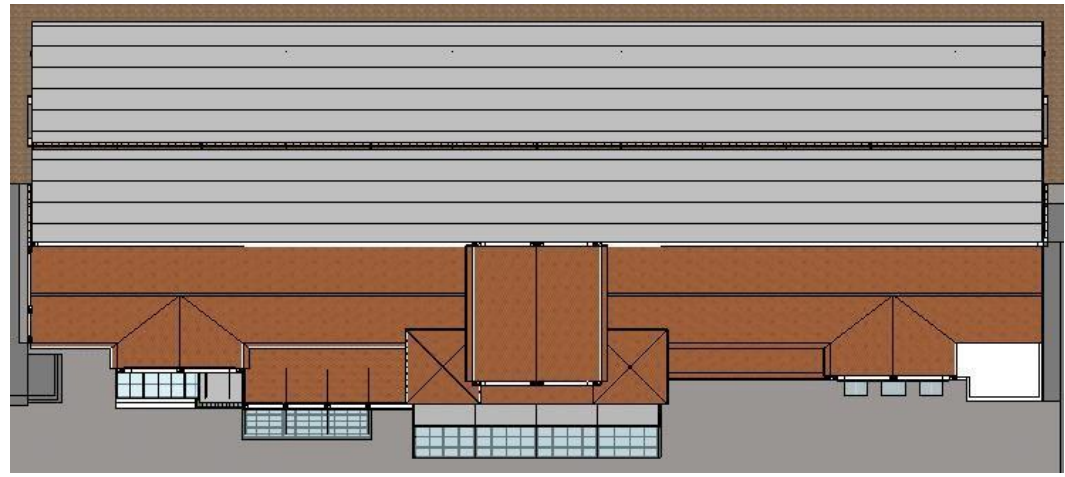

Figur 3. Tatanan Massa Bangunan Utama Stasiun Kejaksan Cirebon

Fungsi-fungsi yang ada pada bangunan ini adalah hall penerima, loket, ruang tunggu, lounge, are VIP, kantor pengelola kereta api, peron, serta retail berupa; Indomaret, Tea Bar, Roti 'O, dan Dunkin Donut. Karena peraturan yang hanya memperbolehkan pemegang tiket masuk ke area peron, ruang-ruang publik seperti retail tidak terhubung, walaupun memiliki pintu ke arah peron dan ke arah ruang tunggu luar. Masing-masing retail memiliki pembatas berupa partisi setinggi \pm 1 meter yang bersifat tidak permanen.

Ruang-ruang privat seperti kantor pengelola, loket, ruang VIP, dan lounge Grage tidak dapat diakses dari luar. Semua pintu mengarah ke peron, kecuali ruang VIP yang memiliki pintu ke arah luar, tetapi sekarang dikunci dan tidak pernah dibuka. Fungsi yang bersifat lebih privat seperti loket dan kantor pengelola memerlukan kartu akses yang hanya dimiliki oleh pegawai PT KAI.

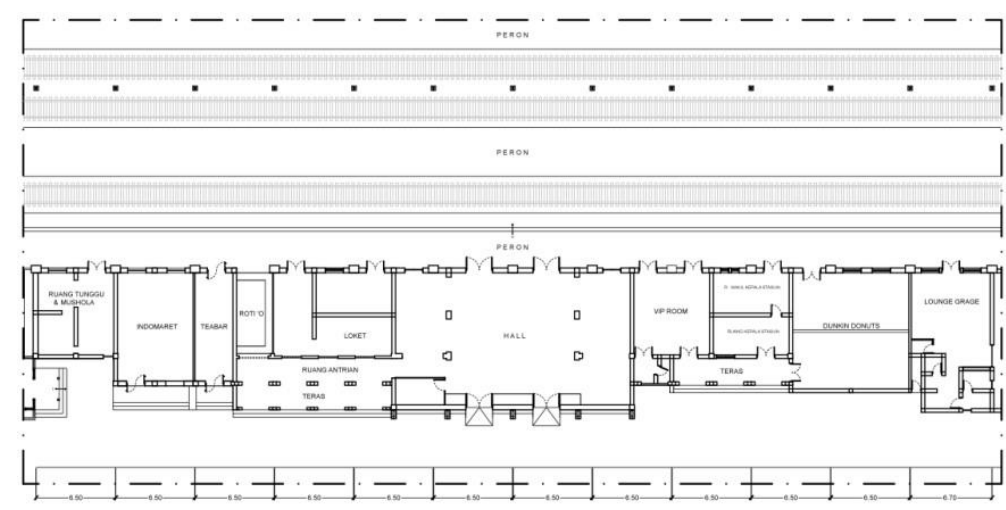

Figur 4. Denah Bangunan Utama Stasiun Kejaksan Cirebon, NTS

Bangunan utama Stasiun Kejaksan Cirebon memiliki bentuk yang monumental, dengan tampak yang simetri. Bagian tengah bangunan menunjukkan hirarki kuat yang terlihat dari perbedaan ketinggian dengan kedua sisinya, serta adanya dua menara yang menghimpit muka 
bangunan bagian tengah. Bangunan berbentuk linear, sejajar dengan Jalan Raya Siliwangi dan dengan rel kereta.

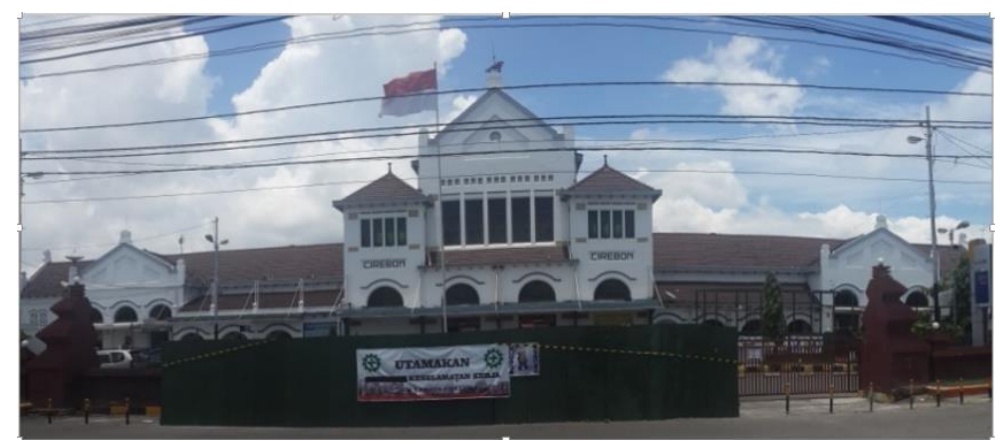

Figur 5. Tampak Muka Bangunan Utama Stasiun Kejaksan Cirebon

Karakter bangunan utama Stasiun Kejaksan Cirebon menunjukkan gaya arsitektur indis. Terlihat dari tampak yang masif dan monumental, adanya bentuk lengkung (arc) atau vault pada dinding, dan ornamen atap yaitu Gavel dan mahkota atap. Gavel dan arc merupakan pengaruh gaya arsitektur Belanda. Arc pada teras ruang-ruang tunggu bersifat sebagai dinding pemikul dengan ketebalan $30 \mathrm{~cm}$. Bentuk lengkung hampir digunakan untuk semua bentuk bukaan bangunan, terutama bovenlicht. Pada bangunan utama Stasiun Kejaksan Cirebon terdapat beragam ornamen bergaya kolonial Belanda seperti hiasan atap, kaca patri, hiasan frame ventilasi, dan bovenlicht.

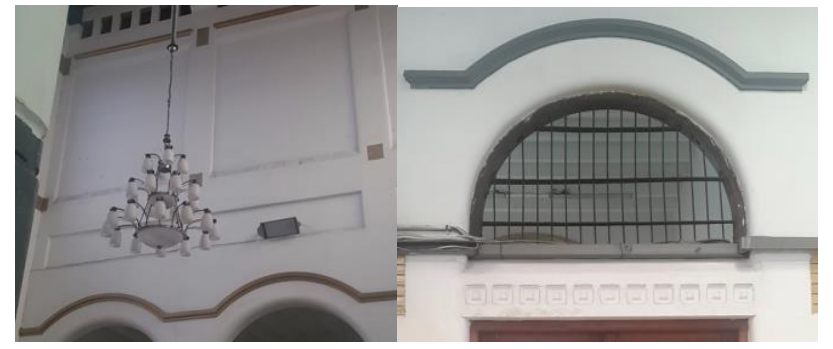

(a)

(b)

Figur 6. (a) Hiasan Berwarna Emas pada Ruang Tengah; (b) Hiasan Berwarna Abu-abu pada Peron

\subsection{PENGARUH FUNGSI DAN HIRARKI RUANG PADA BENTUK ARSITEKTUR BANGUNAN UTAMA STASIUN KEJAKSAN CIREBON}

Pembahasan analisis dibagi menjadi tatanan massa terhadap lingkungan, ruang; fungsi dan hirarki ruang, bentuk massa bangunan, kemudian pengaruh fungsi dan hirarki ruang terhadap bentuk massa bangunan utama Stasiun Kejaksan Cirebon.

\subsubsection{FUNGSI RUANG}

Fungsi seperti stasiun yang merupakan tempat transit atau tempat singgah sementara memiliki aktivitas menunggu, jual-beli tiket, makan, dan istirahat. Aktivitas ini memunculkan kebutuhan seperti ruang tunggu dan ruang istirahat yang ditunjang oleh ruang makan, retail, WC, 
serta pusat pengelolaan bangunan. Ruang-ruang ini akan ditata sesuai pola aktivitas pengguna bangunan, dengan batasan bentuk linear yang menjadi pelingkup.

Fungsi-fungsi ruang di dalam bangunan utama Stasiun Kejaksan Cirebon terbagi menjadi dua, yaitu fungsi utama dan fungsi penunjang. Terlihat dari aktivitas yang terjadi dalam bangunan, fungsi utama stasiun adalah area penerima/hall, area loket, area tunggu, dan peron sebagai tempat perpindahan orang dari stasiun ke kereta. Fungsi penunjang stasiun berupa area makan, minum, bersantai, lounge, WC, mushola, minimarket, dan kantor pengelola.

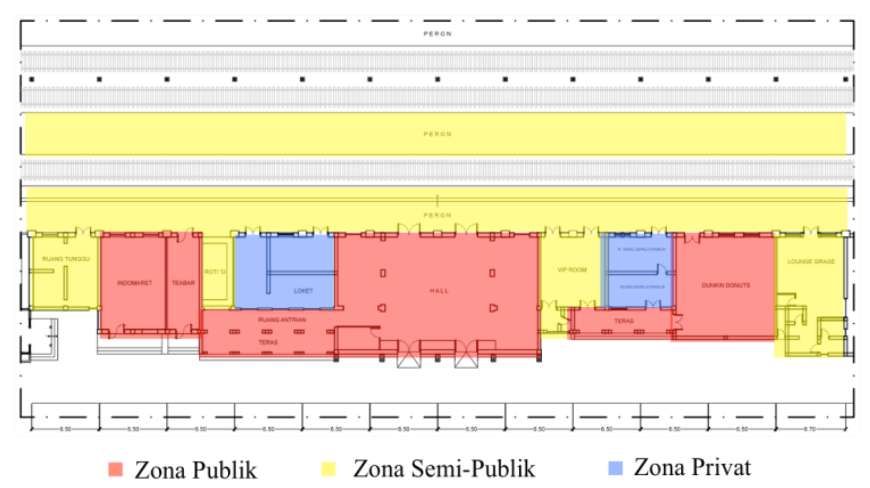

Figur 7. Zonasi Ruang Berdasarkan Pola Aktivitas

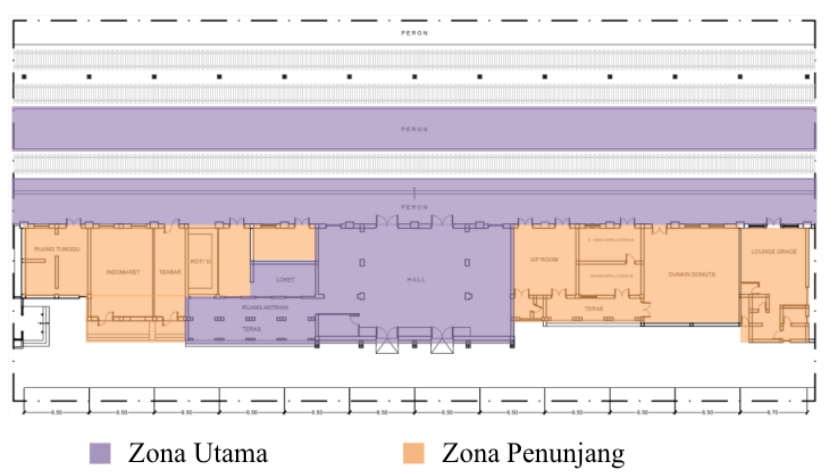

Figur 8. Zonasi Ruang Berdasarkan Fungsi

Zona utama merupakan fungsi yang harus ada di stasiun pada umumnya, seperti hall penerima, area tunggu utama, loket karcis, dan peron, sedangkan fungsi penunjang bersifat sebagai pemenuh kebutuhan, dan bersifat tidak permanen, dapat dihapuskan atau ditambahkan. Zona penunjang dalam bangunan utama Stasiun Kejaksan Cirebon adalah retail, lounge, kantor, dan ruang tunggu VIP.

\subsubsection{HIRARKI RUANG}

Ruang-ruang dalam suatu bangunan cenderung memiliki hirarki yang berbeda-beda. Pada bangunan utama Stasiun Kejaksan Cirebon, hirarki ruang dapat terlihat dari ruang yang mewadahi aktivitas utama yang terjadi dalam bangunan. Aktivitas utama stasiun adalah berangkat dan tiba, serta menunggu, yang menciptakan fungsi peron, ruang tunggu, loket karcis, serta ruang perantara yang menghubungkan peron, ruang tunggu, dan lobi penerima. Ruang-ruang ini merupakan ruang dengan hirarki tertinggi dalam bangunan stasiun. 
Tabel 5. Pembagian Ruang Berdasarkan Hirarki

\begin{tabular}{|l|l|l|}
\hline \multicolumn{1}{|c|}{ Hirarki } & \multicolumn{1}{|c|}{ Fungsi Ruang } & \multicolumn{1}{c|}{ Nama Ruang } \\
\hline Utama & Mewadahi aktivitas utama stasiun; & Peron \\
& tiba, berangkat, dan menunggu. & Ruang Tunggu Utama \\
& & Hall (ruang perantara) \\
& & Lobi (ruang penerima) \\
& & Loket Karcis \\
\hline Penunjang & Mewadahi aktivitas penunjang stasiun; & Ruang Tunggu VIP \\
& makan, minum, bersantai, ke WC, & Retail: Indomaret, Tea Bar, Roti 'O, \\
& sholat. & Dunkin Donuts \\
& & Kantor Pengelola \\
& & Ruang Tunggu Tambahan \\
& & Lounge Grage \\
& & WC \\
\hline
\end{tabular}

\subsubsection{BENTUK MASSA BANGUNAN}

Bentuk massa bangunan utama Stasiun Kejaksan Cirebon dapat dibahas dan dijabarkan melalui beberapa aspek. Aspek pertama adalah orientasi massa yang menunjukkan sikap dan arah bangunan. Aspek kedua adalah tatanan massa bangunan yang mencakup penataan bangunan serta komposisi bentuk bangunan yang menjelaskan bentuk dasar bangunan dan transformasi bentuknya.

Orientasi bangunan utama Stasiun Kejaksan Cirebon terhadap arah mata angin dapat dilihat dari rencana blok bangunan. Bangunan memiliki orientasi Utara-Selatan, walaupun sedikit bergeser, memanjang dari arah Tenggara ke Barat Laut. Bangunan berbentuk linear, berada sejajar dengan Jalan Raya Siliwangi dan rel kereta, dengan muka bangunan menghadap Jalan Raya Siliwangi.
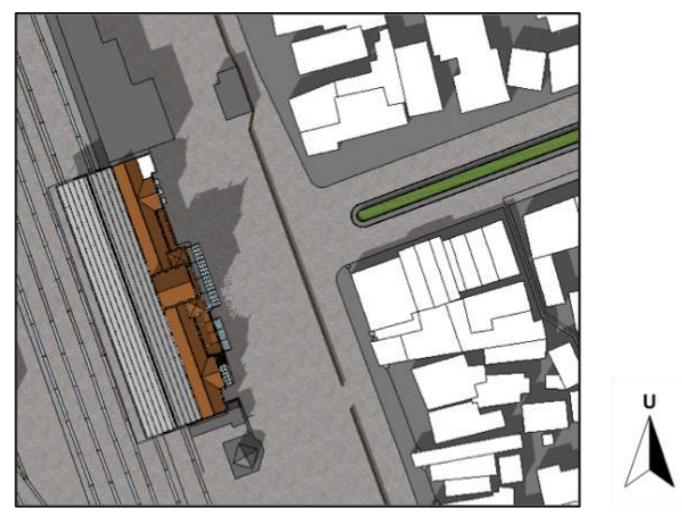

Figur 9. Orientasi Bangunan Utama Stasiun Kejaksan Cirebon

Tatanan massa bangunan utama Stasiun Kejaksan Cirebon berbentuk linear dan memiliki satu massa, tetapi dari perbedaan atap pada bagian muka bangunan dengan peron, terlihat seperti dua massa yang digabung. Bentuk massa bangunan memiliki bentuk dasar geometris persegi dan segitiga. Bentuk bidang persegi digabungkan dengan sesamanya membentuk sebuah bentuk balok yang memanjang. Bentuk segitiga terlihat pada bagian atap. Bentuk-bentuk ini telah mengalami 
perubahan dimensi, ukuran, dan kedalaman atau volume untuk mencapai kesan berat, masif, dan

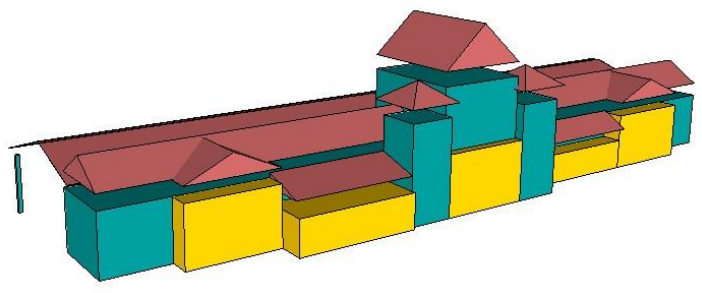
monumental pada bangunan kolonial.

Figur 10. Komposisi Bentuk Massa Bangunan Utama Stasiun Kejaksan Cirebon

Bangunan utama Stasiun Kejaksan Cirebon memiliki beberapa prinsip tatanan lainnya yang terlihat pada tampak bangunan, yaitu sumbu, simetri, hirarki, datum, dan ritma. Sumbu dan simetri pada tampak bangunan membagi massa secara seimbang kiri dan kanannya. Hirarki bentuk pada bagian tengah bangunan yang merupakan entrance. Terlihat pola pengulangan pada tampak depan dan belakang bangunan yang merupakan ritma. Gavel dan bentuk lengkung (arc) sebagai datum yang menjaga kontinuitas visual bangunan.

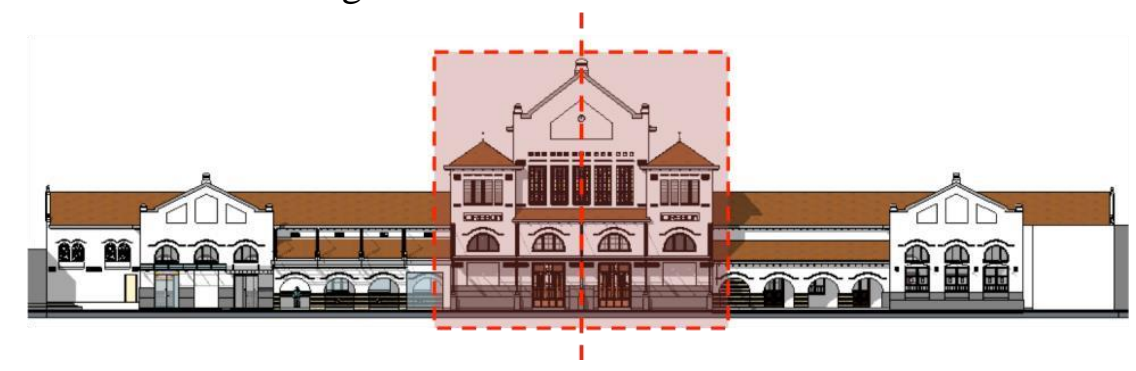

Figur 11. Sumbu, Simetri, dan Hirarki Bentuk pada Bangunan Utama Stasiun Kejaksan Cirebon
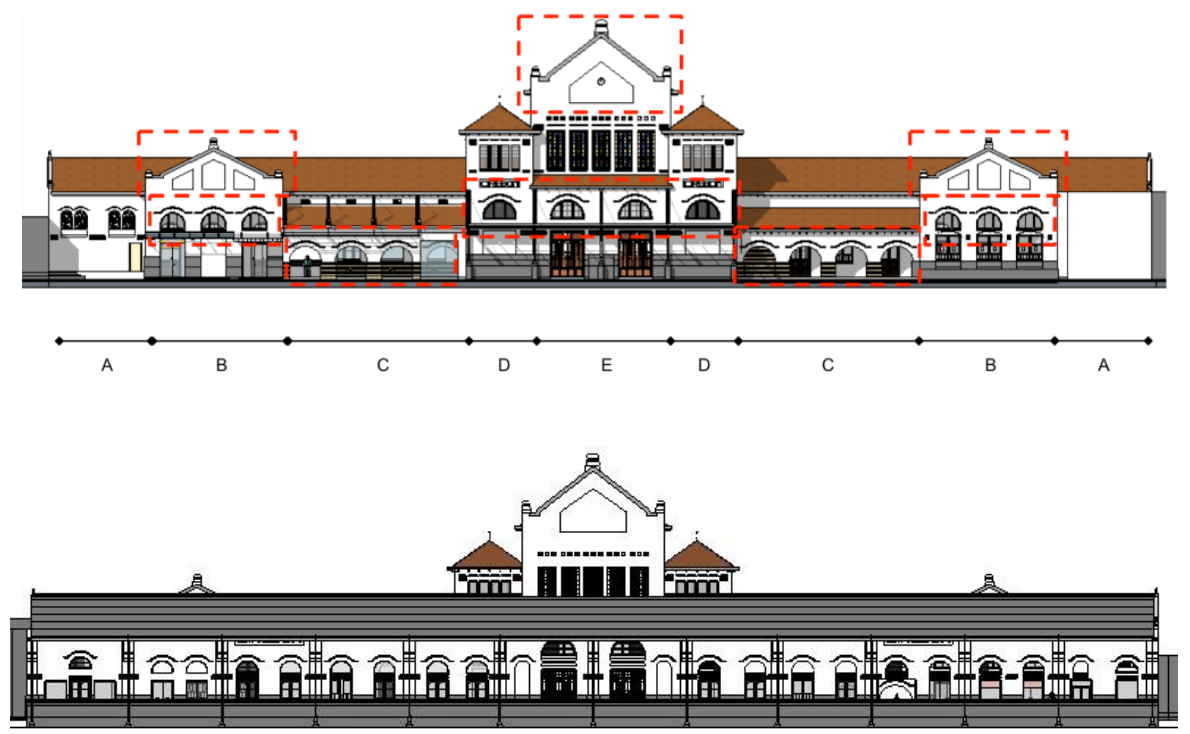

Figur 12. Ritma dan Datum pada Bangunan Utama Stasiun Kejaksan Cirebon

Elemen pelingkup ruang pada bangunan utama Stasiun Kejaksan Cirebon mencakup elemen pelingkup horizontal atas, elemen pelingkup vertikal, dan elemen pelingkup horizontal 
bawah. Elemen pelingkup horizontal atas berupa plafon, elemen vertikal berupa dinding dan seluruh bentuk yang terdapat pada dinding, dan elemen pelingkup horizontal bawah adalah lantai.

Elemen pelingkup horizontal atas atau plafon pada bangunan utama Stasiun Kejaksan Cirebon merupakan bidang datar untuk semua ruang kecuali teras. Jarak plafon dari lantai kuranglebih 5 sampai 6 meter, dan pada bagian tengah mencapai $\pm 10 \mathrm{~m}$ dan $\pm 13 \mathrm{~m}$. Untuk bagian ruang tunggu/ruang menyusui dan indomaret, plafon sudah diganti dan direndahkan menjadi 3 meter dari lantai. Material plafon adalah gypsumboard. Plafon bagian tengah memperlihatkan struktur penopangnya yaitu balok kayu.

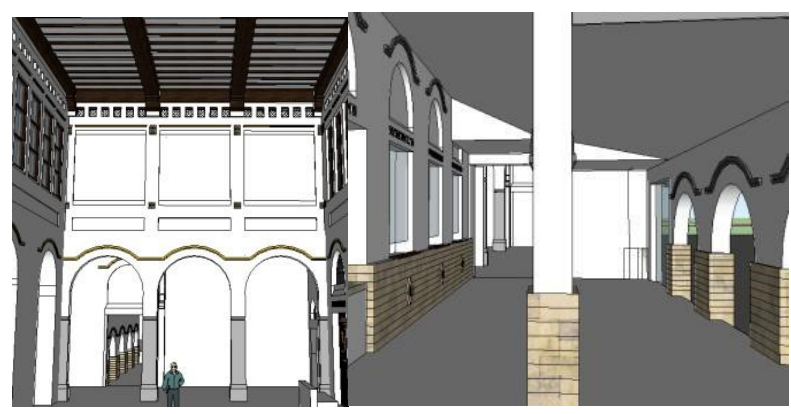

(a)

(b)

Figur 13. (a) Plafon Hall; (b) Plafon Teras

Elemen pelingkup vertikal adalah dinding-dinding pembatas ruang. Pada bangunan utama Stasiun Kejaksan Cirebon, dinding bersifat sebagai struktur penopang atau disebut dinding pemikul, dengan ketebalan bervariasi $30 \mathrm{~cm}, 40 \mathrm{~cm}$, dan $1 \mathrm{~m}$. Bentuk vault pada dinding membantu menahan gaya tarik pada bata. Bentuk ini juga menciptakan irama pada fasad bangunan. Vault pada teras bersifat sebagai bukaan yang menyambungkan ruang dalam dengan ruang luar dengan batasan hanya perbedaan tinggi lantai.

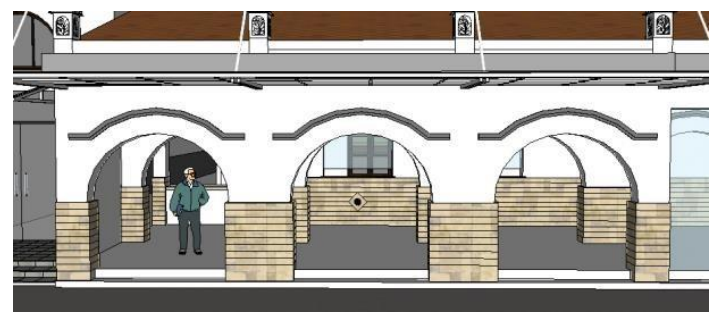

Figur 14. Vault pada Teras Bangunan Utama Stasiun Kejaksan Cirebon

Lubang angin dan bukaan seperti pintu dan jendela juga merupakan bagian dari dinding. Lubang angin pada dinding bangunan utama Stasiun Kejaksan Cirebon berada di dekat ambang plafon. Lubang angin ini memiliki ukiran bercorak kolonial. Lubang-lubang ini terdapat pada bagian tengah bangunan dan disusun sesuai dengan perletakan kolom atau jendela pada hall.

Semua pintu dan jendela pada bangunan utama Stasiun Kejaksan Cirebon memiliki bovenlicht di atasnya, serta ornamen lengkung di atas bovenlicht. Jenis pintu hampir sama, yang 
berbeda adalah pintu di bagian tengah, dengan ukuran pintu yang lebih besar, berbeda material, dan ornamen yang berbeda warna. Jendela memiliki beberapa ragam tetapi hampir satu ukuran.

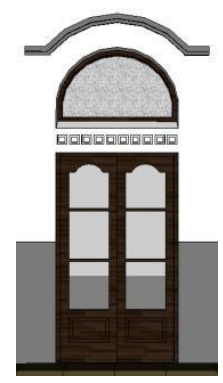

(a)

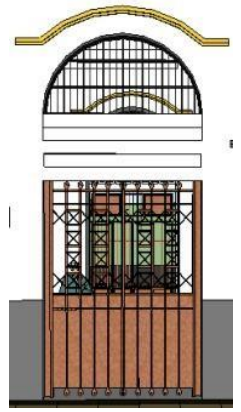

(b)

Figur 15. (a) Pintu Kayu pada Kantor; (b) Pintu Baja dari Hall ke Peron

Elemen lain yang juga merupakan elemen pelingkup vertikal adalah kolom. Kolom struktural dalam bangunan utama Stasiun Kejaksan Cirebon dapat ditemukan pada hall dan peron. Kolom setinggi kurang-lebih 13 meter pada area hall menopang atap pelana yang terlihat pada bagian tengah bangunan. Kolom pada bagian peron menopang truss baja bentang lebar yang membentang sepanjang 15 meter. Kolom pada bagian peron utama menggunakan struktur beton berdimensi 60x80 cm, sedangkan pada ujung satunya menggunakan kolom baja. Penggunaan beton dan baja sebagai struktur merupakan teknologi dari Belanda yang modern pada masanya. Kedua jenis kolom ini juga memiliki hiasan yang bercorak kolonial sehingga menciptakan visual yang indah.

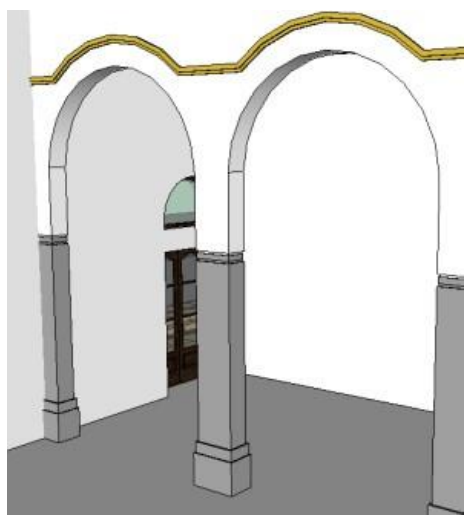

(a)

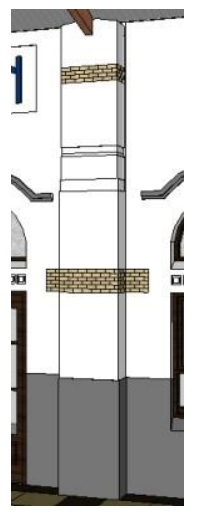

(b)

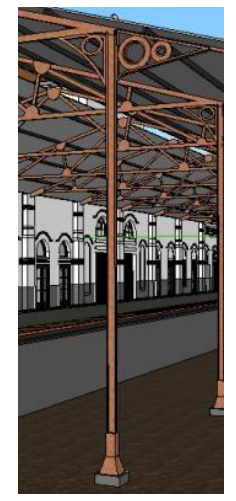

(c)

Figur 16. (a) Kolom Hall; (b) Kolom Beton Peron; (c) Kolom Baja Peron

Ornamen yang melekat pada dinding bangunan utama Stasiun Kejaksan Cirebon antara lain bovenlicht, ornamen berbentuk lengkung pada bukaan dinding, dan wallcover. Warna pada ornamen adalah abu-abu dan emas, bergantung pada penempatannya dalam bangunan. 


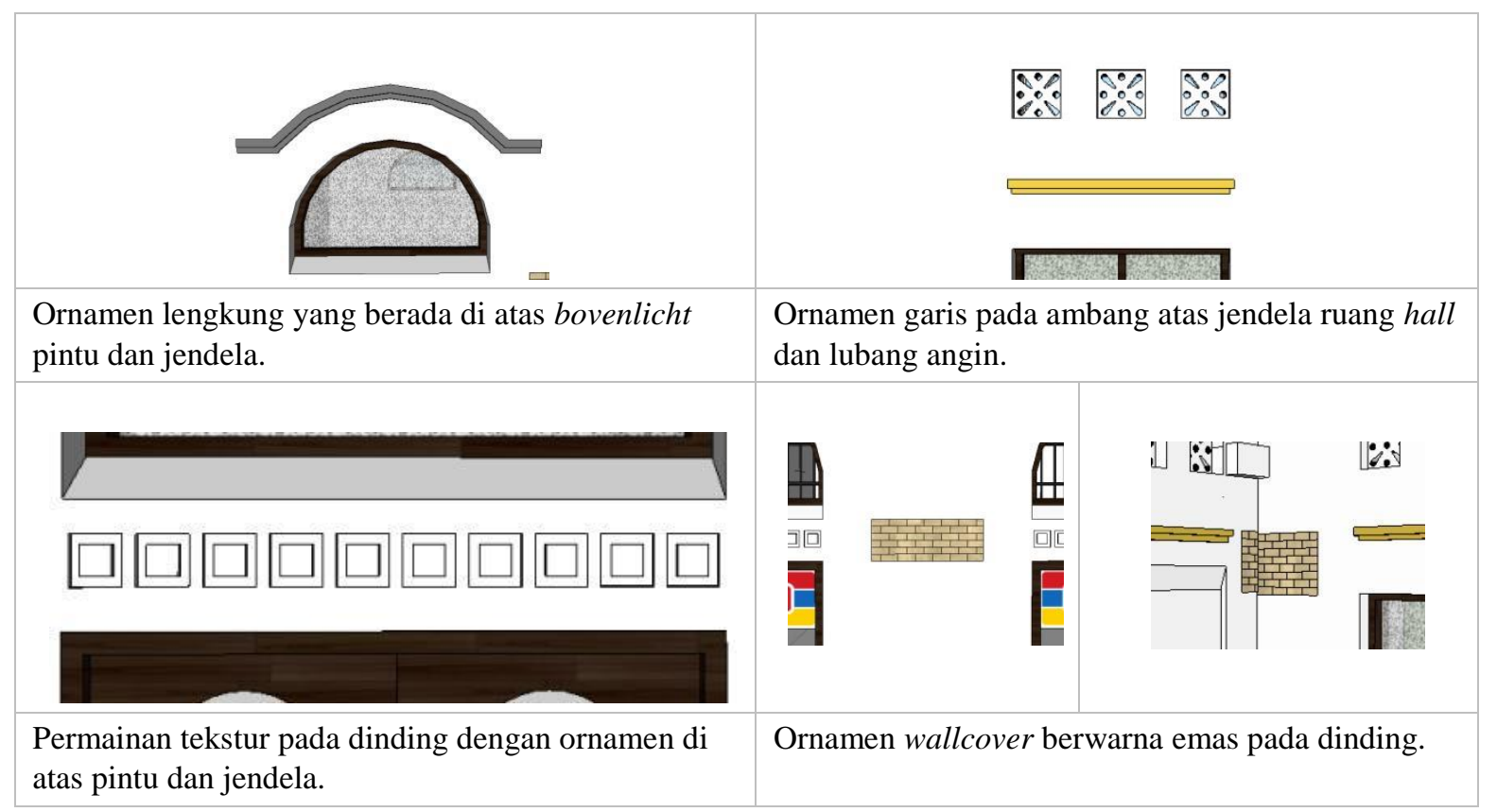

Elemen pelingkup horizontal bawah adalah lantai. Awalnya, seluruh permukaan lantai pada bangunan utama Stasiun Kejaksan Cirebon adalah teraso 20x20 cm. Pelapis lantai kemudian diganti, dengan tetap menyesuaikan dengan fungsi ruang dan mengutamakan keindahan visual, contohnya pada peron utama dan hall stasiun.

Pada hall, lantai yang dipakai adalah keramik putih finis gloss dengan ukuran 60x60 cm, dengan corak yang berada di tengah-tengah ruangan. Pada peron utama, lantai dibuat sesuai dengan grid kolom sehingga memperlihatkan irama atau pola pengulangan pada permukaan lantai. Material lantai yang digunakan adalah keramik berwarna krem dan coklat tua berukuran 60x60 $\mathrm{cm}$. Pola lantai dibentuk membingkai dan simetris, dengan keramik berwarna gelap sebagai bingkai, serta pola yang berada di dalam bingkai.

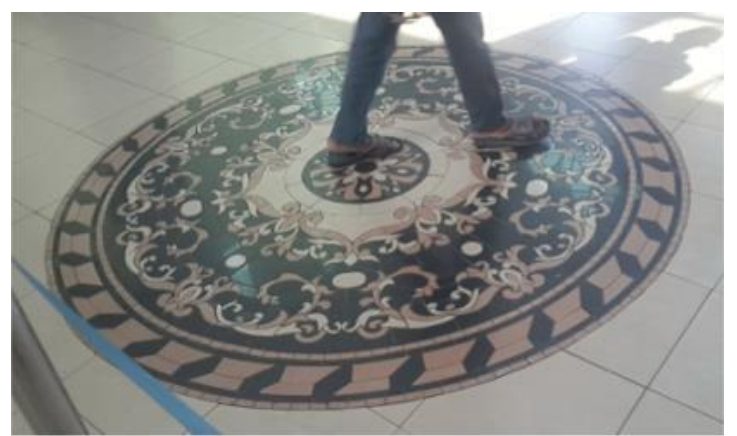

(a)

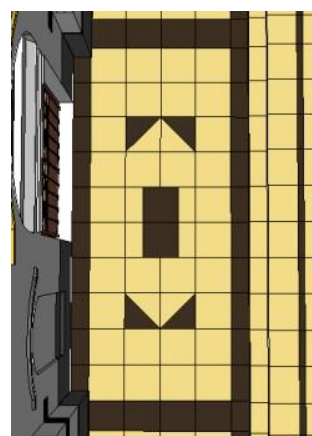

(b)

Figur 17. (a) Lantai Hall; (b) Pola Lantai Peron

\subsubsection{PENGARUH FUNGSI DAN HIRARKI RUANG PADA BENTUK ARSITEKTUR BANGUNAN UTAMA STASIUN KEJAKSAN CIREBON}


Pada bangunan utama Stasiun Kejaksan Cirebon, terlihat jelas pengaruh fungsi, dan khususnya hirarki fungsi, terhadap bentuk arsitektur bangunannya. Seperti yang telah dijelaskan pada bagian ruang bangunan, fungsi bangunan sebagai stasiun mengharuskan bagian peron sejajar dengan rel kereta, sehingga menciptakan linearitas bentuk massa.

Adisi pada bangunan didasarkan pada kebutuhan ruangnya, seperti pada bagian kiri bangunan yaitu loket, ruang teras loket lebih panjang dibanding pada teras di sisi kanan bangunan. Antrean atau kegiatan mengantre memerlukan ruang yang lebih banyak, maka itu ruang ini lebih panjang dari teras di sisi kanan.

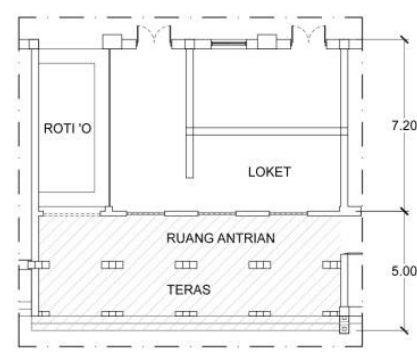

(a)

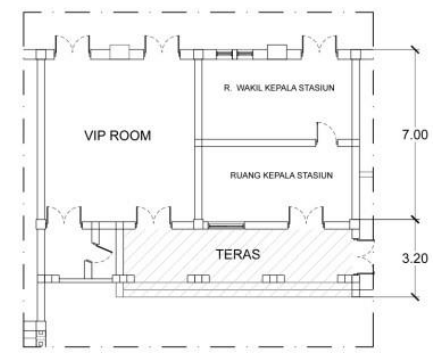

(b)

Figur 18. (a) Teras Sisi Kiri Bangunan; (b) Teras Sisi Kanan Bangunan

Pengaruh fungsi dan hirarki pada bangunan utama Stasiun Kejaksan Cirebon terhadap bentuk juga terlihat pada ruang hall dan ruang tunggu utama. Hall dan ruang tunggu utama merupakan fungsi utama bangunan stasiun yang memiliki hirarki ruang paling tinggi. Hal ini kemudian mempengaruhi bentuk elemen pelingkup ruang yang menaunginya. Perbedaan ukuran dan proporsi massa, penggunaan jenis ornamen, serta proporsi ruang menunjukkan hirarki bentuk yang tinggi.

Tabel 7. Perbedaan Elemen Pelingkup Ruang pada Ruang Hall dan Ruang Tunggu Utama dengan Ruang-Ruang Lain pada Bangunan

Tinggi plafon Dunkin Donuts \pm 6 meter.




\begin{tabular}{|c|c|}
\hline Plafon teras tampak tidak diolah dan hanya permukaan gypsumboard. & $\begin{array}{l}\text { Plafon hall mengekspresikan } \\
\text { struktur penopangnya yaitu kayu. } \\
\text { Terlihat alur balok kayu yang } \\
\text { mengarah ke peron. }\end{array}$ \\
\hline \multicolumn{2}{|c|}{$\begin{array}{c}\text { Proporsi Gavel pada bagian retail dan bagian tengah menunjukkan perbedaan ukuran yang } \\
\text { elas.Gavel } \\
\text { bagian tengah terlihat 1,5 kali lebih tinggi dari Gavel retail. }\end{array}$} \\
\hline \multicolumn{2}{|c|}{$\begin{array}{c}\text { Sama halnya dengan proporsi mahkota atap pada bagian tengah dan bagian retail. Dimensi } \\
\text { mahkota atap }\end{array}$} \\
\hline Permukaan dinding bagian retail dan teras cenderung polos. & $\begin{array}{l}\text { Dinding hall penuh dengan ornamen, } \\
\text { permainan tekstur permukaan, dan } \\
\text { kaca patri sebagai jendela. }\end{array}$ \\
\hline$=$ & \\
\hline $\begin{array}{c}\text { Ornamen berwarna abu-abu pada bagian lain selain pada permukaan dalam } \\
\text { ruang hall. }\end{array}$ & $\begin{array}{l}\text { Ornamen berwarna emas pada ruang } \\
\text { hall. }\end{array}$ \\
\hline
\end{tabular}




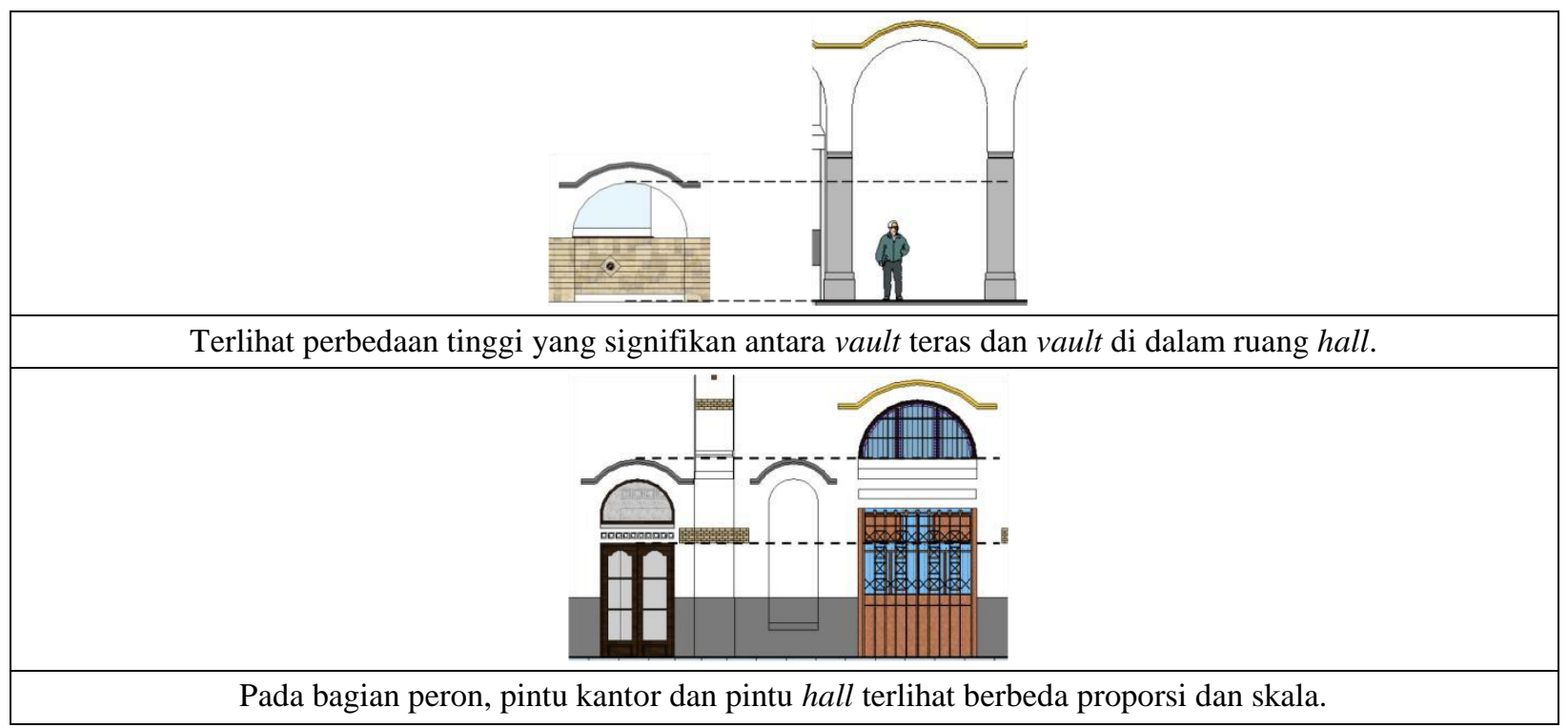

\section{KESIMPULAN}

Dengan mempelajari kaitan fungsi, bentuk, makna serta konsep arsitektur indis, dan menganalisis pengaruhnya terhadap bangunan objek yaitu bangunan utama Stasiun Kejaksan Cirebon, maka dapat diperoleh kesimpulan berupa indikator arsitektur indis pada bangunan utama Stasiun Kejaksan Cirebon dan pengaruh fungsi dan hirarki ruang terhadap bentuk arsitektur bangunan utama Stasiun Kejaksan Cirebon.

Bangunan utama Stasiun Kejaksan Cirebon menerapkan 6 dari 7 poin indikator arsitektur indis yang dikemukakan oleh Handinoto (1996), dengan rincian; tapak luas; bangunan menghadap jalan utama yaitu Jl Siliwangi; bentuk bangunan masif, megah, dan besar; denah simetris tanpa selasar keliling bangunan karena bentuk massa yang linear; atap bangunan merupakan kombinasi perisai dan pelana tanpa ventilasi atap; menggunakan dinding pemikul dan kolom sebagai elemen struktur; menggunakan ornamen bercorak kolonial Belanda. Lantai bangunan sudah tidak asli, material penutup lantai berupa keramik dengan ukuran berbeda dan motif yang disesuaikan dengan ruangan.

Pengaruh fungsi dan hirarki ruang terhadap bentuk arsitektur bangunan utama Stasiun Kejaksan Cirebon adalah; linearitas massa, terlihat dari bentuk mengikuti fungsi, peron sejajar dengan rel kereta sehingga menciptakan pola ruang linear; perbedaan level dan komposisi bentuk atap dan bentuk badan bangunan, terlihat pada bagian tengah bangunan, yang merupakan ruang penerima berupa hall dan ruang tunggu utama. Bentuk bagian tengah lebih besar dan tinggi dibandingkan dengan bagian lain bangunan. Bentuk tengah terdiri dari dua menara sama besar dengan atap terpusat dan satu bentuk kubus tinggi dengan atap pelana.

Tidak hanya dari bentuk luar, bentuk ruang dalam juga mendukung adanya hirarki bentuk. Elemen pembentuk ruang pada ruang yang memiliki hirarki tinggi memperlihatkan perbedaan dengan ruang dengan hirarki lebih rendah dari segi ukuran, material, desain, dan warna. Elemen ini mencakup plafon, dinding, pintu, jendela, lantai, serta elemen hias atau ornamen. Bentuk dan warna material yang digunakan pada ruang bagian tengah bangunan menunjukkan kesan mewah dan megah dibanding bagian lainnya. 


\section{DAFTAR PUSTAKA}

\section{Jurnal:}

Fauzy, B., Antariksa, \& Salura, P. (2011). Memahami Relasi Konsep Fungsi, Bentuk dan Makna Arsitektur Rumah Tinggal Masyarakat Kota Pesisir Utara di Kawasan Jawa Timur (Kasus Studi Rumah Tinggal di Kampung Karangturi dan Kampung Sumber Girang, Lasem). Dimensi Teknik Arsitektur, Vol. 38, No. 2, 79-88. Surabaya: Universitas Kristen Petra.

Handinoto, H., \& Hartono, S. (2006). Arsitektur Transisi di Nusantaradari Akhir Abad 19 ke Awal Abad 20 (Studi Kasus Komplek BangunanMiliter di Jawa pada Peralihan Abad 19 ke 20). Dimensi Teknik Arsitektur, Vol. 34, No. 2, 81-92. Surabaya: Universitas Kristen Petra.

Lin, Yuan, \& Seamon, David, (1994). A Thiis-Evensen Interpretation of Two $20^{\text {th }}$-Century Churches: Le Corbusier's Ronchamp Chapel and Frank Lloyd Wright's Unitarian Church. Power by Design: EDRA Proceedings 24, 130-142. Oklahoma: Environmental Design Research Association.

\section{Buku:}

Ching, Francis D.K. (2002). Arsitektur: Bentuk, Ruang, dan Tatanan. Jakarta: Penerbit Erlangga.

Handinoto. (1996): Perkembangan Kota \& Arsitektur Kolonial Belanda di Surabaya (1870 - 1940). Yogyakarta: Andi Ofset.

Koentjaraningrat. (1994). Kebudayaan Jawa. Jakarta: Balai Pustaka.

Salura, P. (2010). Arsitektur yang Membodohkan. Bandung: CSS Publishing.

Thiis-Evensen, T. (1987). Archetypes in Architecture. New York: Oxford.

\section{Internet:}

Kebudayaan Indis (2013). Diunduh Maret 2016 dari http://artisejarah.blogspot.co.id/2013/01/kebudayaan-indis.html

Stasiun Kejaksan Cirebon (2014). Diunduh Maret 2016 dari http://heritage.kereta-api.co.id/?p=4191

Cirebon Sebagai Kota Peninggalan Kolonial (2015). Diunduh dari
http://disporbudpar.cirebonkota.go.id/2015/10/26/cirebon-sebagai-kota-peninggalan-kolonial/ Arti Kata Akulturasi (2008). Diunduh dari http://kbbi.web.id/akulturasi

Stasiun Cirebon (n.d.) Diunduh dari https://id.wikipedia.org/wiki/Stasiun_Cirebon 